ISSN 0103-5150

Fisioter. Mov., Curitiba, v. 30, n. 3, p. 549-558, Jul./Sep. 2017

Licenciado sob uma Licença Creative Commons

DOI: http://dx.doi.org/10.1590/1980-5918.030.003.A013

\title{
Postural alignment of patients with Chronic Obstructive Pulmonary Disease
}

\author{
Alinhamento postural de pacientes com Doença \\ Pulmonar Obstrutiva Crônica
}

Márcia Aparecida Gonçalves, Davi de Souza Francisco, Caroline Semprebom de Medeiros,
Ana Karla Vieira Brüggemann, Giovana Zarpellon Mazo, Elaine Paulin*

Universidade do Estado de Santa Catarina (UDESC), Florianópolis, SC, Brazil

\begin{abstract}
Introduction: In chronic obstructive pulmonary disease (COPD), airflow resistance impairs respiratory mechanics that may compromise postural alignment. There is a lack of studies that have investigated compromised postures and their possible associations with pulmonary function. Objectives: To compare the postural alignment of COPD patients with apparently healthy individuals; To correlate pulmonary function with postural alignment in the COPD group. Methods: 20 COPD patients and 20 apparently healthy individuals performed: anthropometry, spirometry and postural evaluation. The following postural changes were assessed: lateral head tilt (LHT), shoulder asymmetry (SA1), anterior pelvic asymmetry (APA), lateral trunk tilt (LTT), scapular asymmetry (SA2), posterior pelvic asymmetry (PPA), head protrusion (HP), shoulder protrusion (SP), anterior pelvic tilt (APT) and thoracic kyphosis (TK). Results: There was a statistically significant difference between COPD patients and apparently healthy individuals in the following variables: PPT ( $p=0.021)$, APT $(p=0.014)$ and TK $(p=0.011)$. There was a correlation between pulmonary variables and postural alignment in the COPD group: Forced Volume in one second (FEV1\% pred) and HP $\left({ }^{\circ}\right)(r=0.488, p=0.029)$, FEV1 (\% pred) and APT $\left(^{\circ}\right)(\mathrm{r}=-0.472, \mathrm{p}=0.036)$; Forced Vital Capacity (FVC \% pred) and HP $\left({ }^{\circ}\right)(\mathrm{r}=0.568, \mathrm{p}=0.009)$; FVC (\% pred) and APT $\left(^{\circ}\right)(r=-0.461, p=0.041)$. Conclusion: Postural alignment of the anterior tilt of the right
\end{abstract}

\footnotetext{
* MAG: MS, e-mail: marcya-88@hotmail.com DSF: undergrad, e-mail: davisouzafrancisco@gmail.com CSM: undergrad, e-mail: medeiross.caroline@gmail.com AKVB: MS, e-mail: anakarla_vb@hotmail.com GZM: PhD, e-mail: giovana.mazo@udesc.br EP: PhD, e-mail: elaine.paulin@udesc.br
} 
and left pelvis and thoracic kyphosis is different when compared with COPD patients and healthy individuals. There is a relationship between pulmonary function and postural alignment in COPD patients.

Keywords: Chronic Obstructive Pulmonary Disease. Posture. Photogrammetry.

\title{
Resumo
}

\begin{abstract}
Introdução: Na doença pulmonar obstrutiva crônica (DPOC), a resistência ao fluxo aéreo prejudica a mecânica respiratória que pode comprometer o alinhamento postural. Existe uma escassez de estudos que tenham investigado os comprometimentos posturais e suas possíveis relações com a função pulmonar. Objetivos: Comparar o alinhamento postural entre pacientes com DPOC e indivíduos aparentemente saudáveis; correlacionar a função pulmonar com o alinhamento postural no grupo DPOC. Métodos: 20 pacientes com DPOC e 20 indivíduos aparentemente saudáveis realizaram: antropometria, espirometria e avaliação postural. Foram analisadas as alterações posturais: inclinação lateral da cabeça (ILC), desnivelamento dos ombros (DO), desnivelamento pélvico anterior (DPA), inclinação lateral do tronco (ILT), desnivelamento das escápulas (DE), desnivelamento pélvico posterior (DPP), protrusão da cabeça (PC), protrusão de ombro (PO), báscula anterior da pelve (BAP) $e$ cifose torácica (CT). Resultados: Houve diferença estatisticamente significante entre os pacientes com DPOC e os indivíduos aparentemente saudáveis nas variáveis: DPP $(0,021), B A P(p=0,014)$ e CT $(p=0,011)$. Houve correlação entre as variáveis pulmonares e o alinhamento postural no grupo DPOC: volume forçado no primeiro segundo (VEF1 \%prev) e PC $\left(^{\circ}\right)(r=0,488, p=0,029)$, VEF1 (\%prev) e BAP $\left(^{\circ}\right)(r=-0,472 ; p=0,036)$; Capacidade Vital Forçada (CVF \%prev) e PC $\left(^{\circ}\right)(r=0,568 ; p=0,009)$; CVF \%prev) e BAP $\left(^{\circ}\right)(r=-0,461 ; p=0,041)$. Conclusão: $O$ alinhamento postural da báscula anterior da pelve direita e esquerda e da cifose torácica é diferente quando comparados pacientes com DPOC e saudáveis. Existe relação entre a função pulmonar e o alinhamento postural no paciente com DPOC.
\end{abstract}

Palavras-chave: Doença Pulmonar Obstrutiva Crônica. Postura. Fotogrametria.

\section{Introduction}

Chronic obstructive pulmonary disease (COPD) is characterized by airflow limitation. It is usually progressive and associated with a chronic inflammatory response in the airways due to noxious particles or gases (1). COPD is increasingly recognized as systemic and heterogeneous, and may involve skeletal muscle dysfunction $(2,3)$, heart diseases (4), nutritional dysfunctions (5), biochemical changes (6), osteoporosis (7), psychological disorders (8), as well as the impairment of pulmonary mechanics (9).

Some changes in pulmonary mechanics include lung hyperinflation and air trapping, which are gradually identified in COPD patients. These factors may contribute to increase the anteroposterior diameter of the thorax $(10,11,12)$, horizontalization of the ribs $(11,13)$, as well as to compromise the postural alignment due to compensations in the scapular pelvic girdles and especially in the thoracic spine.
Additionally, COPD patients usually show rectification and shortening of the diaphragm, which may trigger changes in the endothoracic fascia. This shortening may lead to pelvic anteversion and psoitic diaphragmatic hyperlordosis due to the connections of the muscle-aponeurotic connections of the diaphragm muscle with the iliopsoas muscles, the transverse abdominis muscle and the lumbar square muscle (14).

Few studies have evaluated postural alignment of COPD patients $(14,15)$. Dias et al. $(15)$ evaluated the kinematics of the scapular girdle, cervical and thoracic spines of 19 COPD patients and 19 healthy individuals. The study showed a higher elevation of the scapula among COPD patients, compared to healthy individuals. The authors report that this change is likely to occur due to pulmonary hyperinflation that changes the position of the sternum and the scapula. However, they did not find significant differences in the regions of the cervical and thoracic spine between the studied groups. 
Pachioni et al. (14) compared the posture of 15 COPD patients with 15 healthy individuals. The authors observed the presence of three important postural changes in COPD patients: posterior pelvic asymmetry, anterior pelvic asymmetry and increased thoracic kyphosis. The study suggests that such changes could be related to the disease itself; however, the authors did not conduct a correlational analysis between pulmonary function variables and postural alignment.

With the progression of COPD, postural changes may become increasingly evident and it will be more difficult for patients to perform their daily life activities, physical exercises. Also, these changes will mainly interfere in the pulmonary function of these individuals, which is already compromised. Therefore, postural evaluation is of utmost importance in order to identify the existence of changes in the postural alignment and its relation with the pulmonary function in COPD patient. The results obtained in this current study may offer significant contributions to the relationship between posture and respiration, since there are only a few studies in the literature about the presence of postural imbalances in COPD patients and how much this may further compromise their pulmonary function. Moreover, these results may provide further information to develop more appropriate therapy programs combining respiratory strategies, which are already part of pulmonary rehabilitation programs.

Thus, this study aimed: 1 ) to compare postural alignment of COPD patients with apparently healthy individuals; 2) to correlate pulmonary function variables with postural alignment in the COPD group.

\section{Methods}

Study Population and Sample

This is an analytical cross-sectional study with a quantitative approach. It was approved by the Ethics and Research Committee involving Human Subjects under the number CAEE: 08857612.2.0000.0118 and all participants were previously informed about the study and signed an Informed Consent Form, as determined by Resolution 466/12 of the National Health Council.

The sample consisted of 20 "apparently" healthy individuals and 20 patients with a diagnosis of
COPD according to the Global Initiative for Chronic Obstructive Lung Disease (GOLD) classification (1). A diagnostic record, developed by researchers linked to the Laboratory of Respiratory Physiotherapy (LAFIR) at the State University of Santa Catarina (UDESC), was used in order to identify the characteristics of the individuals participating in the study.

For COPD patients, the following inclusion criteria were considered: 1) clinical stability in the last month and at the beginning of the protocol of evaluation; 2) patients who did not use supplemental oxygen; 3 ) inexistence of other associated respiratory or cardiovascular diseases; 4) patients without involvement in pulmonary rehabilitation programs in the 6 months prior to the start of this study; 5) patients who did not undergo recent spinal or lower limb surgeries and/or who hadn't had fractures in the past 6 months. The exclusion criteria were as follows: 1) presence of exacerbations of the disease during the study; 2) clinical intercurrences related cardiorespiratory abnormalities during the evaluations; 3 ) inability to perform any of the study evaluations (lack of understanding or cooperation); and 4) patients' with drawal during the evaluation period.

The group of apparently healthy individuals included: 1) individuals with normal spirometry (FEV1/ FVC $\geq 0.7$; FEV $1 \geq 80 \%$ of predicted, FVC $\geq 80 \%$ of predicted); 2) age, body mass and BMI compatible with COPD group; and 3) inexistence of associated comorbidities. Exclusion criteria were as follows: 1) inability to perform any of the study evaluations (lack of understanding or cooperation); 2) individuals' withdrawal during the evaluation period.

\section{Evaluated parameters}

\section{Anthropometry}

For the anthropometric measurements, a previously calibrated scale and a stadiometer were used for measuring body mass and height, respectively (Welmy ${ }^{\circledR}$ model W200/5, São Paulo, SP, Brazil). The Body Mass Index (BMI) was determined through the equation: body mass/height2. The individuals were classified as underweight $(<18.5 \mathrm{~kg} / \mathrm{m} 2)$, adequate or eutrophic ( $\geq 18.5<25 \mathrm{~kg} / \mathrm{m} 2)$, overweight $(\geq 25<30$ $\mathrm{kg} / \mathrm{m} 2$ ) and obesity ( $\geq 30 \mathrm{~kg} / \mathrm{m} 2$ ) (16). The individuals were instructed to wear light clothes, to remove their shoes and to remain in an upright position. 


\section{Spirometry}

Spirometry was performed to verify the subjects' pulmonary capacity, using a portable digital spirometer (EasyOne ${ }^{\circledR}$, ndd Medical Technologies, Zurich, Switzerland), previously calibrated according to the methods and criteria recommended by the American Thoracic Society and the European Respiratory Society (17). The following parameters were measured: forced vital capacity (FVC), forced expiratory volume in one second $\left(\mathrm{FEV}_{1}\right)$ and $\mathrm{FEV}_{1} /$ FVC ratio before and 15 minutes after inhalation of bronchodilator (BD) salbutamol $(400 \mu \mathrm{g})$ in COPD patients. At least three acceptable maneuvers and two reproducible maneuvers were performed. Spirometry variables are expressed in absolute values and in percent of predicted values of normality, as determined by Pereira et al. (18). The normal lung function test criteria consist of FVC and FEV1 $\geq 80 \%$ of predicted and $\mathrm{FEV}_{1} / \mathrm{FVC} \geq 0.7$.

\section{Postural Alignment}

For the evaluation of the postural alignment, the Postural Assessment Software (PAS/SAPO) validated by Ferreira et al. (19) was used. Before the photographs were taken, male subjects were instructed to wear bermuda shorts, and female subjects to wear bermuda shorts and a top. Initially, anatomical points were identified through the palpatory anatomy in the following regions of the body: head, shoulders, pelvis, spine, upper limbs and lower limbs. After the points had been identified, they were marked with Styrofoam balls, with a diameter of $20 \mathrm{~mm}$, fixed to the body parts with double-sided adhesive tape.

In order to mark the points and define the postural changes that would be evaluated, the protocol developed by Pachioni et al. (14) was used.

In the anterior view, four postural changes were evaluated: lateral head tilt (LHT) by measuring the angle formed between the glabella/mento and the horizontal axis; the shoulder asymmetry (SA1) by the angle formed between the two acromions and the horizontal axis; anterior pelvic asymmetry (APA) measured by the angle between the two anterior superior iliac spines and the horizontal axis; and finally, the lateral trunk tilt (LTT) measured by the angle between the two anterior superior iliac spines and the two acromions.
In the posterior view, two postural changes were evaluated: the scapular asymmetry (SA2), evaluated by the angle formed between the inferior angles of the scapulae and the horizontal axis; and posterior pelvic asymmetry (PPA) was measured by the angle between the two posterior superior iliac spines and the horizontal axis.

In the right lateral view, two postural changes were evaluated: head protrusion (HP), by the angle between the spinous process on the $\mathrm{C} 7$ /tragus and horizontal axis; and shoulder protrusion (SP), by measuring the angle between the spinous process of $\mathrm{C} 7$ /acromion and the horizontal axis.

In the left lateral view, two postural changes were evaluated: the anterior pelvic tilt (APT), obtained by the angle between the anterior-superior/posteriorsuperior iliac spine and the horizontal axis; and thoracic kyphosis (TK), which was measured by the angle between the vertebra T3 and T12 with vertex in the most prominent vertebra.

Next, the individual was placed in a static orthostatic position at a distance of $50 \mathrm{~cm}$ in front of a black wall and next to a plumb line marked with three Styrofoam balls $50 \mathrm{~cm}$ apart from each other them, to allow calibration for the photograph. His/her feet were positioned loosely on top of a black EVA foam mats to shoot the first photograph. The individual was informed, through a verbal command, to remain in a comfortable position, with the eyes fixed at a line, in a relaxed posture. Subsequently, with a white chalk, the foot outlines were drawn so that the individual could stand at the same point for the next photo shoot. After the front and left side views were photographed, the mat was rotated $180^{\circ}$ to obtain the photographs in the posterior and right lateral views (Figure 1).

Two photo cameras (Sanyo BD 20014.1 mega pixels, DSC - W610) were used, which were placed on a tripod (97 cm high). One camera was placed in the front of the individual and the other camera at the left side. However, both cameras were positioned at a distance of $2.30 \mathrm{~m}$ from the participant. The distance and height of the camera was adapted, as previously mentioned, to facilitate visualization of the individual. According to Mota et al. (20), the distance should be sufficient to position the entire body in the center of the image and the resolution should be sufficient to show each of the markers clearly.

The photos were digitalized and analyzed with the PAS software. The analysis of the photos and 
measurements of the angles of the variables of the postural alignment were based on the coordinates of the anatomical points.
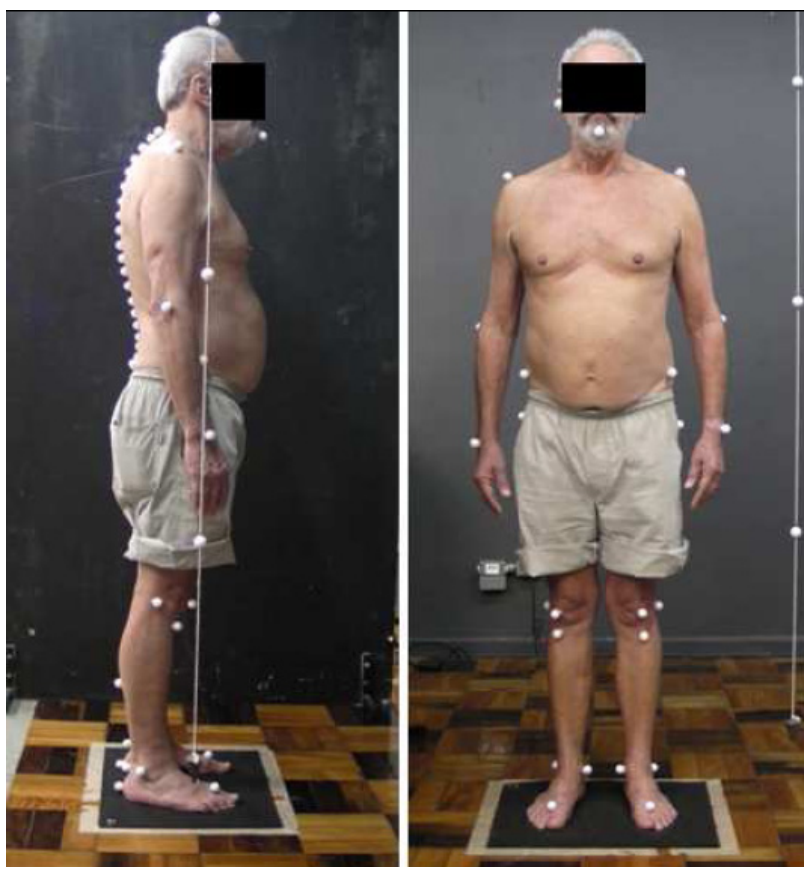

Figure 1 - Evaluation of the postural alignment using PAS. Note: Produced by the author.

Statistical Analysis

The data was analyzed with the SPSS (Statistical Package for the Social Sciences) for Windows, version 20.0 (IBM Corporation, Armonk, NY, USA). The descriptive analysis as mean and standard deviation was applied to all variables. For the sample calculation, the statistical power for 20 subjects per group was calculated, a post hoc sample calculation was performed, using Student's t test with the GPower 3.1 program. The mean values of thoracic kyphosis were determined in both groups: COPD - mean $(207.13 \pm$ 4.83); healthy - mean $(202.81 \pm 5.41)$. The calculated effect was 1.104315 and, using a margin of error of $5 \%$, the power of the calculated sample was 80 for 20 subjects in each group.

To verify the normality of the data, the ShapiroWilk test was applied; to compare shoulder asymmetry, head protrusion, shoulder protrusion and thoracic kyphosis between the groups, the Student's t test was used; and to compare the lateral head tilt, anterior pelvic asymmetry, lateral trunk tilt, scapular asymmetry, posterior pelvic asymmetry and anterior pelvic tilt, the Mann-Whitney U test was used. The Pearson Correlation Coefficient was used to compare the pulmonary variables with lateral head tilt, shoulder asymmetry, scapular asymmetry, head protrusion, shoulder protrusion, anterior pelvic tilt and thoracic kyphosis. The Spearman's correlation coefficient correlated pulmonary function with anterior pelvic asymmetry, lateral trunk tilting and posterior pelvic asymmetry. The significance level for all the tests was set at an alpha of $5 \%$.

\section{Results}

Participants in the study were 40 subjects of both genders ( 20 men and 20 women), who were divided into two groups: group 1 with 20 COPD patients, aged 65.35 $( \pm 6.76)$ years and group 2 with 20 apparently healthy individuals, aged $65.55( \pm 4.57)$ years.

Considering age and anthropometric and pulmonary characteristics between the studied groups (i.e., COPD patients and apparently healthy individuals), Table 1 shows no statistically significant difference between age, body mass, height and BMI, demonstrating that both are homogenous groups for these variables. Regarding pulmonary capacity, a significant difference ( $p<0.001)$ was observed between the groups in the predicted percentage of $\mathrm{FEV}_{1}$ and in the FVC percent of predicted. The best results, on average, were for apparently healthy individuals.

According to GOLD staging system, the patients showed severe COPD and are classified as Stage III (FEV1 $=46.25$ $\pm 14.52 \%$ of predicted).

Regarding the postural alignment of the groups with COPD patients and apparently healthy individuals, table 2 shows a statistically significant difference between the groups for posterior pelvicasymmetry ( $p=0.021)$, anterior pelvic tilt ( $p=0.014)$ and in the thoracic kyphosis angle ( $p=0.011)$. Therefore, it can be observed that COPD patients have a greater posterior pelvic asymmetry, anterior pelvic tilt of the left and right pelvis, and greater thoracic kyphosis angle.

When comparing men and women in the COPD group, the results showed that there was no significant difference in any of the measurements performed by the postural evaluation. Both groups of genders showed similar degrees for the variables of postural alignment (Table 3). 
Table 1 - Characteristics of the studied groups $(n=40)$

\begin{tabular}{|c|c|c|c|}
\hline Variables & $\begin{array}{c}\text { COPD } \\
(n=20)\end{array}$ & $\begin{array}{l}\text { Apparently healthy } \\
(\mathrm{n}=20)\end{array}$ & $\mathrm{p}$-value \\
\hline Gender (M/F) & $10 / 10$ & $10 / 10$ & - \\
\hline Age (years) & $65.35 \pm 6.76$ & $65.55 \pm 4.57$ & 0.913 \\
\hline Body Mass (kg) & $74.95 \pm 19.33$ & $76.60 \pm 12.55$ & 0.751 \\
\hline Height (cm) & $164.25 \pm 0.09$ & $165.95 \pm 0.11$ & 0.613 \\
\hline BMI $\left(\mathrm{kg} / \mathrm{m}^{2}\right)$ & $27.65 \pm 6.10$ & $27.75 \pm 3.09$ & 0.946 \\
\hline $\mathrm{FEV}_{1} / \mathrm{FVC}$ (L) & $0.53 \pm 0.16$ & $0.79 \pm 0.04$ & $<0.001^{*}$ \\
\hline $\mathrm{FEV}_{1}(\mathrm{~L})$ & $1.35 \pm 0.58$ & $2.68 \pm 0.66$ & $<0.001^{*}$ \\
\hline $\mathrm{FEV}_{1}$ (\% pred) & $46.25 \pm 14.52$ & $92.70 \pm 8.57$ & $<0.001^{*}$ \\
\hline FVC (L) & $2.34 \pm 0.82$ & $3.41 \pm 0.82$ & $<0.001^{*}$ \\
\hline FVC (\% pred) & $64.30 \pm 12.26$ & $92.55 \pm 8.40$ & $<0.001^{*}$ \\
\hline
\end{tabular}

Note: The values are expressed as mean \pm standard deviation; M: male; F: female; BMl $(\mathrm{kg} / \mathrm{m} 2)$ : body mass index in kilograms per square meter; FEV1 (\% pred): percent of predicted of forced expiratory volume in one second; FVC (\% pred): percent of predicted of forced vital capacity; ${ }^{\star} \mathrm{p}<0.05$.

Table 2 - Comparison between the postural alignment of COPD patients and apparently healthy individuals $(n=40)$

\begin{tabular}{lrrc}
\hline Variables & \multicolumn{1}{c}{$\begin{array}{c}\text { COPD } \\
(\mathbf{n}=\mathbf{2 0})\end{array}$} & $\begin{array}{c}\text { Apparently healthy } \\
(\mathbf{n}=\mathbf{2 0})\end{array}$ & p-value \\
\hline LHT $\left(^{\circ}\right)$ & $2.87 \pm 2.47$ & $3.28 \pm 2.20$ & 0.616 \\
SA1 $\left({ }^{\circ}\right)$ & $2.72 \pm 1.63$ & $2.77 \pm 1.62$ & 0.923 \\
APA $\left(^{\circ}\right)$ & $2.19 \pm 1.48$ & $1.47 \pm 1.25$ & 0.065 \\
LTT $\left(^{\circ}\right)$ & $2.90 \pm 2.52$ & $2.84 \pm 1.47$ & 0.598 \\
SA2 $\left(^{\circ}\right)$ & $2.49 \pm 1.70$ & $2.39 \pm 1.85$ & 0.655 \\
PPA $\left(^{\circ}\right)$ & $3.03 \pm 1.99$ & $1.80 \pm 1.25$ & $0.021^{*}$ \\
HP $\left({ }^{\circ}\right)$ & $42.41 \pm 6.91$ & $43.44 \pm 6.66$ & 0.637 \\
SP $\left({ }^{\circ}\right)$ & $157.28 \pm 12.52$ & $150.04 \pm 13.57$ & 0.088 \\
APT $\left(^{\circ}\right)$ & $7.55 \pm 4.29$ & $4.55 \pm 2.92$ & $0.014^{*}$ \\
TK $\left(^{\circ}\right)$ & $207.13 \pm 4.83$ & $202.81 \pm 5.41$ & $0.011^{*}$ \\
\hline
\end{tabular}

Note: The values are expressed as mean \pm standard deviation. LHT: lateral head tilt; SA1: shoulder asymmetry; APA: anterior pelvic asymmetry; LTT: lateral trunk tilt; SA2: scapular asymmetry; PPA: posterior pelvic asymmetry; HP: head protrusion; SP: shoulder protrusion; APT: anterior pelvic tilt; TK: thoracic kyphosis; $\left({ }^{\circ}\right)$ : measurements in degrees; ${ }^{*} \mathrm{p}<0.05$.

Table 3 - Comparison of postural alignment between men and women in the COPD group $(\mathrm{n}=20)$

\begin{tabular}{lccc}
\hline Variables & $\begin{array}{c}\text { COPD } \\
(\mathbf{n}=\mathbf{2 0})\end{array}$ & $\begin{array}{c}\text { Apparently healthy } \\
(\mathbf{n}=\mathbf{2 0})\end{array}$ & p-value \\
\hline LHT $\left(^{\circ}\right)$ & $2.27 \pm 2.38$ & $3.47 \pm 2.54$ & 0.290 \\
SA1 $\left({ }^{\circ}\right)$ & $2.72 \pm 1.75$ & $2.73 \pm 1.59$ & 0.989 \\
APA $\left({ }^{\circ}\right)$ & $1.82 \pm 1.21$ & $2.57 \pm 1.69$ & 0.268 \\
LTT $\left(^{\circ}\right)$ & $2.51 \pm 2.55$ & $3.29 \pm 2.56$ & 0.504 \\
SA2 $\left({ }^{\circ}\right)$ & $2.86 \pm 2.17$ & $2.14 \pm 1.04$ & 0.360 \\
PPA $\left({ }^{\circ}\right)$ & $2.43 \pm 1.07$ & $3.64 \pm 2.53$ & 0.189 \\
HP $\left({ }^{\circ}\right)$ & $40.71 \pm 6.75$ & $44.12 \pm 6.98$ & 0.283 \\
SP $\left({ }^{\circ}\right)$ & $160.88 \pm 11.86$ & $153.68 \pm 12.70$ & 0.207 \\
APT $\left({ }^{\circ}\right)$ & $7.13 \pm 4.12$ & $7.98 \pm 4.64$ & 0.670 \\
TK $\left(^{\circ}\right)$ & $206.11 \pm 4.03$ & $208.15 \pm 5.54$ & 0.360 \\
\hline
\end{tabular}


This study showed a relationship between pulmonary variables and measures of postural alignment in the COPD patients group. A positive correlation was found between $\mathrm{FEV}_{1}$ (\% pred) and head protrusion $(\mathrm{r}=0.488, \mathrm{p}=0.029)$; FVC ( $\%$ pred $)$ and head protru$\operatorname{sion}(r=0.568 ; p=0.009)$. However, there was a negative correlation between $\mathrm{FEV}_{1}$ (\% pred) and anterior pelvic tilt $(\mathrm{r}=-0.472 ; \mathrm{p}=0.036) ; \mathrm{FVC}(\%$ pred $)$ and anterior pelvic tilt $(\mathrm{r}=-0.461 ; \mathrm{p}=0.041)$. There was no correlation between the other variables related to pulmonary function with measures of postural alignment (Table 4).

\section{Discussion}

The current study identified two major postural changes in COPD patients compared to apparently healthy individuals: greater angle in thoracic kyphosis, in the anterior pelvic tilt and posterior pelvic asymmetry. Our results are in agreement with the study conducted by Pachioni et al. (14), who also compared the postural alignment of 15 COPD patients and 15 healthy individuals and found a statistically significant difference in these same variables.

Table 4 - Correlation between pulmonary function and measures of postural alignment of COPD group $(n=20)$

\begin{tabular}{|c|c|c|c|c|c|}
\hline \multirow{2}{*}{ Variables } & FEV1/FVC (L) & FEV1 (L) & FEVI (L) & FVC (L) & FVC (\% pred) \\
\hline & $r$ & $r$ & $r$ & $r$ & $r$ \\
\hline LHT $\left(^{\circ}\right)$ & $0.083(0.727)$ & $-0.109(0.647)$ & $0.015(0.949)$ & $-0.070(0.769)$ & $0.044(0.855)$ \\
\hline SA1 $\left(^{\circ}\right)$ & $0.367(0.111)$ & $0.280(0.231)$ & $0.377(0.101)$ & $0.299(0.201)$ & $0.431(0.058)$ \\
\hline $\operatorname{APA}\left({ }^{\circ}\right)$ & $-0.078(0.745)$ & $-0.208(0.379)$ & $-0.193(0.416)$ & $-0.148(0.532)$ & $-0.222(0.348)$ \\
\hline $\operatorname{LTT}\left({ }^{\circ}\right)$ & $0.342(0.140)$ & $0.224(0.341)$ & $0.351(0.129)$ & $0.209(0.377)$ & $0.380(0.099)$ \\
\hline SA2 $\left(^{\circ}\right)$ & $0.028(0.906)$ & $0.253(0.282)$ & $0.125(0.600)$ & $0.206(0.384)$ & $0.079(0.742)$ \\
\hline $\operatorname{PPA}\left({ }^{\circ}\right)$ & $-0.274(0.242)$ & $-0.330(0.155)$ & $-0.383(0.960)$ & $-0.371(0.107)$ & $-0.373(0.105)$ \\
\hline $\mathrm{HP}\left({ }^{\circ}\right)$ & $0.358(0.121)$ & $0.288(0.218)$ & $0.488^{*}(0.029)$ & $0.228(0.334)$ & $0.568^{* *}(0.009)$ \\
\hline $\mathrm{SP}\left({ }^{\circ}\right)$ & $0.057(0.813)$ & $0.133(0.577)$ & $0.090(0.705)$ & $0.023(0.924)$ & $-0.128(0.589)$ \\
\hline APT $\left(^{\circ}\right)$ & $-0.399(0.081)$ & $-0.409(0.073)$ & $-0.472^{*}(0.036)$ & $-0.388(0.091)$ & $-0.461 *(0.041)$ \\
\hline TK $\left({ }^{\circ}\right)$ & $-0.062(0.796)$ & $0.040(0.868)$ & $-0.015(0.950)$ & $0.056(0.814)$ & $0.005(0.984)$ \\
\hline
\end{tabular}

Note: The values are expressed as correlation (r); ${ }^{*} p<0,05 ;{ }^{* *} p<0,001 ; \mathrm{FEV} 1$ (\% pred): percent of predicted of forced expiratory volume in one second; FVC (\% pred): percent of predicted of forced vital capacity; LHT: lateral head tilt; SA1: shoulder asymmetry; APA: anterior pelvic asymmetry; LTT: lateral trunk tilt; SA2: scapular asymmetry; PPA: posterior pelvic asymmetry; HP: head protrusion; SP: shoulder protrusion; APT: anterior pelvic tilt; TK: thoracic kyphosis; $\left({ }^{\circ}\right)$ : measurements in degrees.

The greater angle in the thoracic kyphosis of the COPD group may be caused by increased anteriorposterior diameter of the thorax $(10,11,12)$ and horizontalization of the ribs $(11,13)$, possibly due to pulmonary hyperinflation and air trapping, which is characteristic of COPD (21).

In COPD patients, the disease itself and other factors, such as, aging, may be related to the increase in thoracic kyphosis. Usually, thoracic kyphosis undergoes changes with aging, as it is often related to aspects such as, osteoporosis, obesity, sedentary lifestyle and muscular weakness $(22,23,24,25)$, which are commonly observed in elderly individuals.

However, in this study, there was no statistically significant difference in mean age between the evaluated groups, which reinforces the hypothesis that this postural change may be related to the progress and the systematic changes caused by COPD and not only due to the aging process.

Another change found in COPD patients was a greater angle in the anteriorization of the tilt and greater posterior pelvic asymmetry, on the right and left sides, when compared with apparently healthy individuals, which was also reported by Pachioni et al. (14). Thus, this change shows a possible relationship between this postural imbalance and the progress of the disease. Considering that participants of this study are elderly subjects and that body posture may change over the years (22), an increase in anterior pelvic tilt is likely to be caused by the aging process.

However, the mean age between both groups is very similar and this postural change was more relevantly identified in COPD patients. Consequently, the cause of this change should not be attributed solely to 
aging, but also to physiopahtological factors related to the disease as these patients often show respiratory distress that potentiate the recruitment of accessory muscles and thoracic cavity muscles (26), triggering the apical respiratory pattern. This respiratory pattern elevates the muscle action potentials, such as the sternocleidomastoid, resulting in shortening, loss of flexibility and changes in the position of the head and compensations in the scapular girdle, pelvic spine and thoracic spine $(27,28)$.

In order to verify if these changes in postural alignment were related to pulmonary function, a correlation between these variables was performed. The results showed that there is a positive correlation of FEV1 (\% pred) and FVC (\% pred) with the head protrusion angle and a moderate negative correlation with the anterior pelvic tilt. However, no correlation was found between the other pulmonary variables.

According to the results, postural imbalances found in the head position of COPD patients may be related to the impairment of respiratory function, as well as to the compensatory postures adopted by the patient during respiratory attacks. According to Brech et al. (29), obstruction or narrowing of pharynx, airspace has been associated with anteriorization and extension of the head position in order to rectify the path for airflow passage and facilitate the entry of air to the lower airways.

Due to these factors, COPD patients adopt postures that may facilitate the action of respiratory muscles. This is extremely worrying. According to Okuro et al. (30), the anteriorization of the head increases the activity of the sternocleidomastoid muscle and causes elevation of the thoracic cavity. Consequently, the thoracoabdominal mobility will be decreased and the ventilatory efficiency promoted by the diaphragm will be compromised. This mechanical disadvantage intensifies the inspiratory effort and generates a vicious circle of muscular tension, postural alteration and increased respiratory work.

Thus, it is observed that the changes resulting from the disease process can trigger the postural imbalances that were found in these patients. However, it is difficult to quantify these imbalances because the literature does not offer reference values for postural alignment for elderly people. For this reason, this study was careful to compare the postural alignment of COPD patients and apparently healthy individuals within the same age group.
To further analyze the postural imbalances in COPD patients, a comparative analysis was carried out between men and women. The results showed similarities in the degrees of the angles of the postural alignment between the groups. These results may be due to the similarity of age of the sample studied as both groups showed typical natural aging, which causes changes and gradual reductions in the capabilities of the various systems of the human body.

There is a lack of studies comparing postural alignment between elderly women and men. However, some studies have shown that postural changes in the region of the thoracic curvature are generally more pronounced in women due to hormonal factors and muscle weakness of the spinal extenders $(31,32)$.

A limitation of this study is the evaluation of thoracic kyphosis using the PAS method because the visualization of the markers may be difficult in the lateral view, which compromises accurate measurement of the individual's thoracic kyphosis. The literature has already reported that the PAS software is not the best tool to evaluate thoracic kyphosis. It proposes other instruments such as the Cobb index (gold standard) and measurement using the flexicurve ruler (33). However, the main objective of this study was to assess not only thoracic kyphosis, but also the postural alignment as a whole.

To date, the literature has not presented values for postural alignment for this population. Therefore, it was not possible to establish a comparison between the values found in this study with values considered as "normal". For this reason, we compared the values found in COPD group with those in healthy individuals. However, it is believed that the results of the present study may positively contribute as a basis for further studies aiming to establish these reference values and to investigate the major changes that may occur in postural alignment with advancing age.

\section{Conclusion}

COPD patients assessed by the Postural Assessment Software (PAS) showed changes in the postural alignment, namely, greater angle in the thoracic kyphosis, in the anteriorization of the pelvic tilt and in the posterior pelvic asymmetry when compared with apparently healthy individuals.

In the COPD group, there was a relationship between pulmonary function and some variables of the 
postural alignment. However, it cannot be stated that the physiopathological factors of the disease are able to influence postural alignment or that posture can further compromise pulmonary function. Thus, the lack of published studies on postural alignment associated with the compromised respiratory function of COPD patients reinforces the need for further studies.

\section{References}

1. Global initiative for chronic obstructive lung disease (GOLD). Global Strategy for the diagnosis, management and prevention of chronic pulmonary disease. 2016 [cited 2016 Nov 6]. Available from: https://tinyurl.com/jeuvymu.

2. Maltais F, Decramer M, Casaburi R, Barreiro E, Burelle Y, Debigaré R, et al. An official American Thoracic Society/European Respiratory Society statement: update on limb muscle dysfunction in chronic obstructive pulmonary disease. Am J Respir Crit Care Med. 2014;189(9):e15-62.

3. Cebollero P, Zambom-Ferraresi F, Hernández M, Hueto J, Cascante J, Anton MM. Inspiratory fraction as a marker of skeletal muscle dysfunction in patients with COPD. Rev Port Pneumol. 2017;23(1):3-9.

4. Chen W, Thomas J, Sadatsafavi M, FitzGerald JM. Risk of cardiovascular comorbidity in patients with chronic obstructive pulmonary disease: a systematic review and meta-analysis. Lancet Respir Med. 2015;3(8):631-9.

5. Schols AM, Ferreira IM, Franssen FM, Gosker HR, Janssens W, Muscaritoli M, et al. A Nutritional assessment and therapy in COPD: a European Respiratory Society Statement. Eur Respir J. 2014;44(6):1504-20.

6. Agustí A, Edwards LD, Rennard SI, MacNee W, Tal-Singer R, Miller BE, et al. Persistent systemic inflammation is associated with poor clinical outcomes in COPD: a novel phenotype. PLoS One. 2012;7(5):e37483.

7. Romme EA, Smeenk FW, Rutten EP, Wouters EF. Osteoporosis in chronic obstructive pulmonary disease. Expert Rev Respir Med. 2013;7(4):397-410.

8. Rzadkiewicz M, Bråtas $\mathrm{O}$, Espnes GA. What else should we know about experiencing COPD? A narrative review in search of patients' psychological burden alleviation. Int J Chron Obstruct Pulmon Dis. 20166;11:2295-2304.
9. O’Donnell DE, Webb KA, Neder JA. Lung hyperinflation in COPD: applying physiology to clinical practice. COPD Res Pract. 2015;1(1):4.

10. Oliva IB, Cortopassi F, Rochester CL, Rubinowitz AN. Combined pulmonary fibrosis and emphysema syndrome: a radiologic perspective. Monaldi Arch Chest Dis. 2011;75(4):220-34.

11. Aliverti A, Quaranta M, Chakrabarti B, Albuquerque $\mathrm{AL}$, Calverley PM. Paradoxical movement of the lower ribcage at rest and during exercise in COPD patients. Eur Respir J. 2009;33(1):49-60.

12. Oliveira PC. Apresentações clínicas da DPOC. Pulmão RJ. 2013;22(2):15-8.

13. Soares SMTP, Carvalho CRR. Intolerância ao exercício em pacientes com doença pulmonar obstrutiva crônica. Rev Cienc Med. 2009;18(3):143-51.

14. Pachioni CAS, Ferrante JA, Panissa TSD, Ferreira DMA, Ramos D, Moreira GL, et al. Avaliação postural em pacientes com doença pulmonar obstrutiva crônica. Fisioter Pesqui. 2011;18(4):341-5.

15. Dias CS, Kirkwood RN, Parreira VF. Orientation and position of the scapula, head and kyphosis thoracic in male patients with COPD. Can J Respir Ther. 2009;45(2):30-4.

16. Brasil. Ministério da Saúde. Orientações para coleta e análise de dados antropométricos em serviços de saúde: norma técnica do sistema de Vigilância Alimentar e Nutricional - SISVAN. Brasília: Ministério da Saúde; 2011.

17. Miller MR, Hankinson J, Brusasco V, Burgos F, Casaburi $\mathrm{R}$, Coates A, et al. Standardisations of spirometry. Eur Respir J. 2005;26:319-38.

18. Pereira CA, Sato T, Rodrigues SC. New reference values for forced spirometry in white adults in Brazil. J Bras Pneumol. 2007;33(4):397-406.

19. Ferreira EA, Duarte M, Maldonado EP, Burke TN, Marques AP. Postural assessment software (PAS/ SAPO): validation and reliability. Clinics (Sao Paulo). 2010;65(7):675-81.

20. Mota YL, Mochizuki L, Carvalho GA. Influência da resolução e da distância da câmera nas medidas feitas pelo software de avaliação postural (SAPO). Rev Bras Med Esporte. 2011;17(5):334-8. 
21. Yamaguti WPS, Paulin E, Shibao S, Chammas MC, Salge JM, Ribeiro M, et al. Air trapping: The major factor limiting diaphragm mobility in chronic obstructive pulmonary disease patients. Respirology. 2008;13(1):138-44.

22. Gasparotto LPR, Reis CCI, Ramos LR, Santos JFQ. Autoavaliação da postura por idosos com e sem hipercifose torácica. Ciênc \& Saúde Coletiva. 2012;17(3):717-22.

23. Roghani T, Zavieh MK, Manshadi FD, King N, Katzman W. Age-related hyperkyphosis: update of its potential causes and clinical impacts - narrative review. Aging Clin Exp Res. 2016;1-11.

24. Kado DM, Huang MH, Karlamangla AS, Cawthon $P$, Katzman W, Hillier TA, et al. Factors associated with kyphosis progression in older women: 15 years' experience in the study of osteoporotic fractures. J Bone Miner Res. 2013;28(1):179-87.

25. Katzman WB, Wanek L, Shepherd JA, Sellmeyer DE. Age-Related Hyperkyphosis:Its Causes, Consequences, and Management. J Orthop Sports Phys Ther. 2010;40(6):352-60.

26. Miranda EF, Malaguti C, Corso SD. Peripheral muscle dysfunction in COPD: lower limbs versus upper limbs. J Bras Pneumol. 2011;37(3):380-8.

27. Pasinato F, Corrêa ECR, Peroni ABF. Avaliação da mecânica ventilatória em indivíduos com disfunção têmporo-mandibular e assintomáticos. Rev Bras Fisioter. 2006;10(3):285-9.
28. Corrêa ECR, Bérzin F. Efficacy of physical therapy on cervical muscle activity and on body posture in school-age mouth breathing children. Int J Pediatr Otorhinolaryngol. 2007;71(10):1527-35.

29. Brech GC, Augusto CS, Ferrero P, Alonso AC. Alterações posturais e tratamento fisioterapêutico em respiradores bucais: revisão de literatura. Acta ORL. 2009;27(2):80-4.

30. Okuro RT, Morcillo AM, Ribeiro MAGO, Sakano E, Conti PBM, Ribeiro JD. Respiração bucal e anteriorização da cabeça: efeitos na biomecânica respiratória e na capacidade de exercício em crianças. J Bras Pneumol. 2011;37(4):471-9.

31. Katzman B, Wanek L, Shepherd JA, Sellmeyer DE. Age-Related Hyperkyphosis: Its Causes, Consequences, and Management. J Orthop Sports Phys Ther. 2010;40(6):352-60.

32. Bandeira FM, Delfino FC, Carvalho GA, Valduga R. Comparação entre a cifose torácica de idosos sedentários e praticantes de atividade física pelo método flexicurva. Rev Bras Cineantropom Desempenho Hum. 2010;12(5):381-6.

33. Teixeira FA, Carvalho GA. Confiabilidade e validade das medidas da cifose torácica através do método flexicurva. Rev Bras Fisioter. 2007;11(3):199-204 .

Received in 11/06/2015

Recebido em 06/11/2015

Approved in 02/07/2017

Aprovado em 07/02/2017 